\title{
CHILE ACTUAL: ANATOMÍA DE UN MITO DE TOMÁS MOULIAN*
}

\author{
Margarita Iglesias Saldaña
}

Cuando me invitaron a reseñar este libro (Chile actual: Anatomía de un mito) de Tomás Moulian, más allá de lo grato que me resulta, tome conciencia de que este año se cumplen quince años de la primera edición del libro que marcó un hito en los análisis postdictatoriales en Chile y alcanzó un éxito editorial no visto hasta entonces para un libro que se adentra en las profundidades controvertidas de la realidad de nuestra sociedad.

Releerlo hoy, y proponer su lectura o relectura, me ha parecido de una actualidad más que indispensable cuando el transformismo o gatopardismo, demostrado en esta obra, ha comenzado a evidenciarse y criticarse en las calles por las nuevas generaciones que buscan reposicionar la justicia social en este país. Un país aún herido de muerte de las viejas propuestas, revolucionarias o reformistas, que buscaron resolver las ya más que centenarias diferencias de clases, étnicas, y regionales, así como discriminaciones múltiples, entre las que hoy podemos identificar como las de género y etarias en el campo de la lucha social y política del Chile actual, a quince años de este libro, que ya es un clásico.

Primera reflexión a modo de pregunta: ¿Chile actual, sigue siendo ese páramo del ciudadano y el paraíso del consumidor con el que se abre la propuesta de la primera parte del libro?

Según el diccionario de la Real Academia Español, RAE, "páramo" es un terreno yermo, raso y desabrigado, un lugar sumamente frío y desamparado. Creo que este páramo, que hace quince años impresionaba en el Chile de la época, ha cambiado radicalmente su radiografía; hoy vemos un terreno fecundo, conflictuado por esa ciudadanía que busca un derrotero en las calles animadas por movimientos sociales que se demarcan tanto de las administraciones políticas de algunas consagradas y -más que nunca- autoconsagradas coaliciones, como de las expresiones vandálicas en nombre de una violencia política reactiva hacia un Estado de un país ya transformado, según la constatación y explicitación de Moulian en este libro: "En la matriz de una dictadura terrorista devenida dictadura constitucional se formó el Chile actual, obsesionado por el olvido de esos orígenes" (pág. 18).

Uno de los aspectos más sugerentes de este libro está en el tratamiento de lo material en el hecho fundacional de este Chile actual gestado con el golpe de Estado en 1973: "Bombardear desde el aire el Palacio de Gobierno ya expresa una voluntad de tabla rasa, de crear un nuevo Estado sobre las ruinas del otro. Se realizó con ello la 'destrucción del Estado precedente' (...) de lo simbólico, porque cuando Allende se suicida ya estaba muerto" (pág. 30).

* Moulian, T., Chile actual: Anatomía de un mito, Santiago de Chile: LOM Ediciones, 1997, 386 páginas, véase online en: http://trs.sagepub.com/content/7/2/354.full.pdf 
Al comenzar el libro con el análisis de los primeros años postdictatoriales, Moulian historiza el devenir de un Chile perplejo y prisionero de las transacciones políticas cupulares para construir las políticas de consenso que buscaron legitimizar y democratizar la Constitución dictatorial de 1980, incentivando el despegue económico a través del consumismo; lo que el autor denomina "ciudadanos credit-card", quienes cambiaron los espacios públicos de las protestas por los paseos dominicales de los mall. Un consenso como "etapa superior del olvido... como una presunta desaparición de las divergencias respecto de los fines", donde la otrora oposición a la dictadura va transformando su discurso crítico con "las estrategias de blanqueo con la construcción de la imagen del Chile modelo". Cuestión que, en el mismo análisis, el autor previene sobre la fragilidad de dichos acuerdos e intentos de consenso dado que: "La potencia generada por la explosión social, revela la labilidad de todo lo establecido y deja espacio al recambio de protagonistas, a la aparición en el escenario histórico de fuerzas nuevas" (pág. 20), y que dado los acontecimientos de los movimientos sociales de los dos últimos años (especialmente sobre la educación en 2011, y los regionales; Magallanes, Punta Arenas, 2011; Aysén, Calama, 2012) vuelven a evidenciar que los consensos construidos a espaldas de los movimientos sociales y ciudadanos tiene fecha de término. Como lo dijo Moulian el año recién pasado: "La gran difusión que ha tenido el movimiento estudiantil ha planteado temas que tienen que ver con la educación, pero también con algo más global sobre el carácter de la democracia que se vive. En el movimiento estudiantil está latente una crítica global a la sociedad neoliberal, en lo económico y social, del Chile actual. Estamos en un momento excepcional que supera el inmovilismo del pasado y que tiene como protagonistas a los estudiantes, igual como ocurría antes" (Moulian, 2011).

Esta actualidad de la propuesta del libro, que repasa históricamente desde la perspectiva del autor el desarrollo del Estado y la sociedad chilena a lo largo del siglo XX, para explicarnos así el consenso postdictatorial de las cúpulas institucionales y políticas de Chile, es al mismo tiempo una posibilidad de entender el reposicionamiento de las fuerzas en tensión en el Chile del siglo XXI, que desnuda la fragilidad de los acuerdos del pasado reciente con las interpelaciones ciudadanas democráticas de este siglo. Como algunos de los protagonistas de esos acuerdos del blanqueamiento lo reconocen hoy desde sus puestos parlamentarios:

Quizás nos equivocamos con la derecha hace 20 años, al decidir ser duros en lo político, pero respetuosos en lo personal. Habían llegado al Parlamento elegidos por el pueblo, les enrostrábamos su responsabilidad colectiva en dictadura pero no los descalificábamos en su pasado personal, por eso repetía de las ideas todo, de las personas nada. Y a pesar de las disputas políticas en el trabajo diario, construimos ciertas relaciones personales cordiales hasta amistosas, sin que nadie claudicara en sus principios.

Yo pensaba que el pueblo nos obligaba a no acusar a nadie en base a suposiciones... (Patricio Hales, 2012). 


\section{REFERENCIAS BIBLIOGRÁFICAS}

Zúñiga, D., Entrevista "La vuelta de Moulian", en Revista Qué Pasa, Santiago, 2 de septiembre 2011.

Hales, P., Intervención en el Parlamento, 11 enero 2012, véase online en: http://www.elmostrador.cl/noticias/pais/2012/01/17/el-dia-de-furia-del-diputado-patricio-hales 